\title{
A Method for comprehensively Assessing Economic Trade-Offs of New Irrigation Developments
}

\author{
C. Petheram ${ }^{1}$ - J. Hughes ${ }^{1}$ - L. McKellar ${ }^{2}$ • S. Kim ${ }^{1}$ • \\ L. Holz ${ }^{3,4}$ - P. Poulton ${ }^{5}$ M. Kehoe ${ }^{1,6} \cdot$ S. Podger ${ }^{1,7}$. \\ G. Podger $^{1} \cdot$ D. McJannet ${ }^{2} \cdot$ J. Hornbuckle $^{1,8}$
}

Received: 1 June 2015 / Accepted: 18 July 2016 /

Published online: 1 August 2016

(C) The Author(s) 2016. This article is published with open access at Springerlink.com

\begin{abstract}
To meet the anticipated increase in global demand for food and fibre products, large areas of land around the world are being cleared and infrastructure constructed to enable irrigation, referred to herein as 'greenfield irrigation'. One of the challenges in assessing the profitability of a greenfield irrigation development is understanding the impact of variability in climate and water availability and the trade-offs with scheme size, cost and the sensitivity of crop yield to water stress. For example, is it more profitable to irrigate a small area of land most years or a large area once every few years? And, is it more profitable to partially or fully water the crop? This paper presents a new method for efficiently linking a river system model and an agricultural production model to explore the financial trade-offs of different management choices, thereby enabling the optimal scheme area and most appropriate level of farmer risk to be identified. The method is demonstrated for a hypothetical but plausible greenfield irrigation development based around a large dam in the Flinders catchment, northern Australia. It was found that a dam and irrigation development paid for and operated by the same entity is not, under the conditions examined in this analysis, economically sustainable. The method could also be
\end{abstract}

\section{Petheram \\ cuan.petheram@csiro.au}

1 CSIRO Land and Water Flagship, Canberra, Australia

2 CSIRO Land and Water Flagship, Brisbane, Australia

3 CSIRO Land and Water Flagship, Newcastle, Australia

4 Present address: NSW Department of Water, Sydney, Australia

5 CSIRO Agriculture Flagship, Toowoomba, Australia

6 Present address: Global Institue for Water Security, University of Saskatoon, Saskatoon, Canada

7 Present address: WMAwater, Sydney, Australia

8 Present address: Centre for Regional and Rural Future, Deakin University, Griffith, Australia 
used to explore the impact of different management strategies on the agricultural production and profitability of existing irrigation schemes within a whole of river system context.

Keywords Economics · Hydrology·Agriculture $\cdot$ Northern Australia $\cdot$ Greenfield $\cdot$ Management

\section{Introduction}

With the world's population projected to grow from 6 billion (in 2000) to 9 billion people in 2050 (UNESCO 2009), and the majority of this growth likely to occur in the tropics, particularly subSaharan Africa and South Asia, growth in food production will need to mirror population growth (UNESCO 2009). Currently irrigated agriculture produces approximately $40 \%$ of the world's crop output, with much of the irrigation water being supplied by large dams. It is expected that in the future $80 \%$ of additional food production will need to come from irrigated land.

To meet the anticipated increase in demand for food, fibre and fuel products, large areas of land around the world, remote from existing irrigation schemes, are being cleared and infrastructure constructed to enable irrigation, referred to herein as 'greenfield irrigation'. In Brazil and China alone it is estimated that approximately 30 and 14 million hectares of 'greenfield' area has the potential to be developed for irrigation, respectively (Aquastat 2015). Greenfield irrigation and access to reliable water have also been identified as a potential means of enabling regional development of the sparsely populated and largely undeveloped northern $40 \%$ of Australia (PMC 2014).

However, greenfield irrigation developments are contentious. Their construction can result in changes to surrounding and downstream environments and to existing industries, towns and local communities (e.g. Vorosmarty et al. 2003; Kingsford 2000; WCD 2000). Where substantial infrastructure needs to be constructed to support a new irrigation development, questions of profitability often arise (Ansar et al. 2014), particularly if the development involves an injection of public capital or other subsidy (e.g. tax concessions).

One of the challenges in evaluating whether a greenfield irrigation development is likely to be profitable is matching the size of the irrigated area and level of risk that farmers may be prepared to accept. This is related to the quantity and reliability of water supply. For example, is it more profitable to irrigate a small area of land most years or a large area once every few years? This decision is further complicated by the fact that the economic optimum (i.e. the planted area that returns the greatest profit) is often not equivalent to the agronomic optimum (i.e. the planted area that returns the greatest yield per hectare), and sometimes it is preferable to plant a larger area and impose water stress on a crop, in order to achieve the highest profit (Stirzaker 1999).

Although numerous studies have assessed the economics of large, dam-based irrigation, and generally found poor returns to investment (e.g. Davidson 1972; Fan et al. 2007; Molle 2008), the authors could only find one study in the literature that explicitly takes the above listed factors into consideration. In this study, Hassanzadeh et al. (2014) used a systems dynamics approach, encapsulating a water resource model, a 'dynamic' irrigation model and socio-economic variables, to investigate trade-offs between irrigation and hydropower production. More typically, however, the profitability of a greenfield irrigation scheme is simply assessed on a demand at a nominal reliability, and an average crop water use and crop yield. This approach is routinely undertaken by practitioners in government and the consulting industry (Morwood 1983; AECOM 2009; DEEDI 2011).

River system models aim to provide estimates of stream flow at various points along a river network and are, therefore, semi-distributed in nature. River system models are based on the concept of the water balance, though there is great variety in what processes 
these models represent and their scale of operation. While some may represent processes such as irrigation, and/or environmental flows (e.g. Vaze et al. 2013; Welsh et al. 2012), this is not standard. Where assessments of crop production do exist within these model frameworks they are based on very simple relationships with water consumption. Furthermore, few if any extend further to consider the economic performance of irrigation production, while still enabling the impacts of the river regulation to be analysed within the whole of river system. Consequently, this study is distinct from those in the scientific literature because it presents a method by which the trade-offs between scheme area, capital and operation costs, physical risk (e.g. variability in climate and streamflow), farmer risk and the sensitivity of crop yield to water stress is explored. This enables the scheme area and annual planting area decisions that provide the maximum profit to be identified.

To properly explore and understand the economic trade-offs between these variables requires the use of coupled hydrological and agricultural production models and for the results to be presented within a financial framework. Consequently the objectives of this paper are to:

- Outline a method for undertaking a hydro-agronomic assessment of a potential greenfield irrigation development within a whole of catchment context, thereby enabling other analysis to be undertaken simultaneously (e.g. an assessment of ecological change as a result of perturbations to downstream flow).

- Outline a method for efficiently linking a river system model and an agricultural production model.

- Set out a financial analysis framework to evaluate the profitability of greenfield irrigation areas, for which there are few precedents to follow in the scientific literature.

- Outline typical estimates of cost for large irrigation developments in northern Australia, for which there is an absence of information in unclassified publications.

The method is demonstrated in an assessment of a potential irrigation development in the Flinders catchment, northern Australia.

\section{Hypothetical Scenario}

In this paper, a hypothetical potential irrigation development near Cloncurry, in the Flinders catchment, northern Australia (Fig. 1) was used to demonstrate the method. The scenario was based on local aspirations (e.g. NQ Register 2014; ABC Rural 2014) and recent economic development evaluations in the region (Meateng et al. 2012).

Water for irrigation would be supplied from a $16 \mathrm{~m}$ high earth embankment dam built approximately $20 \mathrm{~km}$ upstream of Cloncurry (248 GL capacity), upstream of an area called Cave Hill. The cost of dam construction has been estimated to be about AUD\$249 million, though there are considerable geological uncertainties for dam construction in the general area (Petheram et al. 2013). Under this nominal configuration, water would be released from the dam to a sheet piling weir (approximately $1500 \mathrm{ML}$ capacity) re-regulating structure $50 \mathrm{~km}$ downstream of the dam, thereby reducing the transmission losses normally involved in unregulated river systems. Water would be pumped from upstream of the weir (assuming a $10-\mathrm{m}$ head requirement) into a main distribution channel on the left bank. Irrigation water is assumed to be distributed within a farm (i.e. from the farm gate to the field) using open channels. Once at the field, water is applied using spray irrigation. 
Fig. 1 Location of Flinders catchment (shaded area) and town of Cloncurry (solid circle)

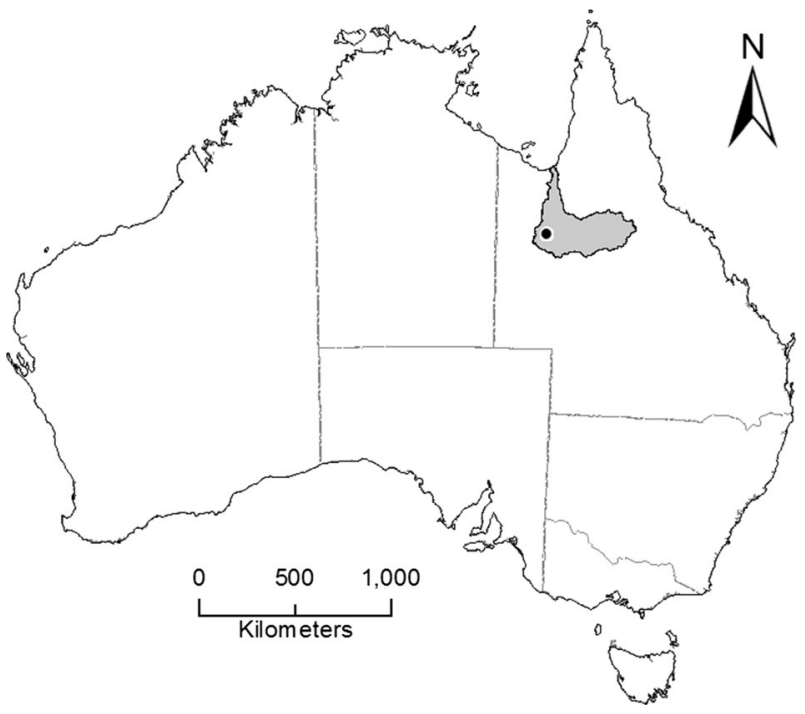

Downstream of Cloncurry over 70,000 ha of friable clay loam soils and cracking clay soils moderately suited to irrigated cereal crop production are located downstream of the dam site and these are described in Bartley et al. (2013). Before irrigation development, the area would require more intensive assessment of usable areas.

The mean annual rainfall at Cloncurry is $477 \mathrm{~mm}$ (between 1890 and 2011) and is highly seasonal and variable between years. There are no climatic limitations to growing Sorghum (grain) during the dry season near Cloncurry, though there is a low frost risk between June and August.

\section{Materials and Methods}

The materials and methods has been broken into four sections:

1. Key analysis tools.

2. Linking river system and crop production models.

3. Selecting the appropriate size of the irrigation development and farmer risk profile for a greenfield irrigation site.

4. Financial analysis framework.

\subsection{Key Analysis Tools}

\subsubsection{River System Model}

The framework for this analysis was a Source river system model (Welsh et al. 2012) for the Flinders catchment developed by Lerat et al. (2013). River system models are a genre of hydrological models that describe the movement of water along a regulated or unregulated stream network. The node-link network is a fundamental component of a river system model. Nodes represent locations along the river where flows enter, are 
stored, extracted, lost or measured. Links are used to model the movement of water between nodes. Inflows constitute the main source of water in a river network model. Hydrologic routing links introduce lag and attenuation of flow to mimic the effect that a river reach has on delaying flow and modifying the shape of the hydrograph. The nonlinear Laurenson routing model (Laurenson 1959), widely used in Australia, was used for routing the flow. Observed data were used for those inflow nodes where flow measurements were available. The Sacramento rainfall-runoff model (Burnash et al. 1973) was used for gap filling and extension of these records and estimating ungauged inflows (see Lerat et al. 2013). A loss model was added to the river network model to represent transmission losses that occur in most semi-arid stream networks due to evaporation and exchanges between surface and groundwater systems (Lange, 2005).

Irrigation demands in Source are traditionally generated using one of the inbuilt conceptual Irrigator Demand Models (Bethune and Podger 2013), which estimate crop water demand using the FAO56 method (Allen et al. 1998).

The Flinders River model was modified to reflect the hypothetical development scenario outlined in Section 2. This involved incorporating and parameterising:

- the dam, located at the nearest upstream node in the existing Source model (i.e. the location was conservatively selected so as not to overestimate inflows);

- conveyance and field application efficiencies;

- an extraction point at the re-regulation structure adjacent to the irrigation development; and

- a 'resource assessment', which limits orders to the allocated water resource. An annual water resource accounting method was utilised.

The model was re-configured so that existing water users downstream of the irrigation development did not experience a reduction in the reliability of their supply.

Table 1 lists the conveyance efficiency assumptions used in this analysis. In total, the conveyance and application efficiency from the storage to the crop is about $56 \%$. These values are likely to represent best practice.

\subsubsection{Apsim Crop Production Model}

Given the limited experience of crop growing seasons, yields, water requirements and farming systems in the Flinders catchment, and that there were no nearby irrigation areas in adjacent regions, a numerical biophysical crop models was required. APSIM (Keating et al. 2003) being a biophysical process agricultural production model has superior capability to predict crop yields in comparison to the conceptual irrigation demand model provided in Source. APSIM is structured around plant, soil and management modules and provides accurate predictions of crop production potential in relation to climate, genotype, soil and management factors while addressing long-term resource management issues.

\subsection{Linking River System and Crop Production Models}

Although APSIM is better able to predict crop yields and water use behaviour than the Source conceptual crop models, APSIM is a plot scale model and consequently does not have the capability to assess water availability beyond the paddock. Hence, a joint approach was adopted where: 
Table 1 Assumed conveyance efficiencies for the hypothetical irrigation development and associated dam

\begin{tabular}{|c|c|c|}
\hline Component & Efficency $(\%)$ & Comment \\
\hline River conveyance efficiency & $75 \%$ & $\begin{array}{l}\text { Distance between dam and re-regulating structure } \\
\text { is about } 50 \mathrm{~km} \text {. Long distance, relatively low } \\
\text { volumes. The advantage is that the first releases } \\
\text { of water occur towards the end of the wet season } \\
\text { when the bed sands are already near saturation }\end{array}$ \\
\hline Channel distribution efficiency & $90 \%$ & $\begin{array}{l}\text { Representative of evaporation loss from re-regulation } \\
\text { structure and channel loss between river and farm } \\
\text { gate. Assumed best practice }\end{array}$ \\
\hline On-farm distribution efficiency & $97 \%$ & $\begin{array}{l}\text { Representative of on-farm evaporation and seepage } \\
\text { loss from farm gate to edge of field. Assumed } \\
\text { best practice }\end{array}$ \\
\hline Field application efficiency (spray) & $85 \%$ & Lateral move sprinklers \\
\hline Overall efficiency & $56 \%$ & \\
\hline
\end{tabular}

Source was used to i) assess water availability to the crop; and ii) perturb streamflow downstream of the irrigation area as a result of irrigation extractions; while APSIM was used to estimate water demands to: i) determine the most appropriate sowing date; ii) develop daily crop coefficients for use by the Source conceptual crop model.

A water availability versus crop yield regression model was then developed based on the APSIM results to rapidly evaluate the sensitivity of the crop yield to the availability of water as determined by Source.

\subsubsection{Determination of Most Appropriate Sowing Date}

Prior to the parameterisation of the Source Irrigator Demand model, the APSIM model was used to evaluate the most appropriate sowing date for Sorghum (grain) at Cloncurry. Simulations were undertaken using soil representative of the irrigation area (i.e. with a plant available water capacity of $150 \mathrm{~mm}$ ) and the sorghum module of APSIM for a range of sowing dates (September to May) and using the long term climate dataset from Cloncurry (1890 to 2011). The simulations indicated that sowing in March on a relatively full soil water profile maximises grain production while minimising the amount of irrigation required to meet crop demand. Planting in March would usually avoid frost damage at development stages of flowering (May).

\subsubsection{Ensuring Consistency between Source and the APSIM}

The Source crop model component uses the FAO 56 method (Allen et al. 1998) to estimate crop water requirement in order to calculate water demands. This calculation requires a crop coefficient $(\mathrm{Kc})$ that is unique to each crop and its stage of growth from sowing to maturity. This is a widely accepted method for determining crop water requirements in a simple way. However, obtaining realistic values for $\mathrm{Kc}$ is not simple, especially where crops are to be grown in environments where no measurements have been made of crop water use. In this study daily Kc values were obtained for Sorghum (grain) for a March sowing, based on outputs from the APSIM crop model. This approach ensures that the quantity and timing of Source crop water requirements were very similar to those generated by APSIM. The choice of 
soil parameter values for the Source Irrigation Demand Model was informed through the development of the APSIM model for the Cloncurry irrigation area.

Custom Kc curves for the crop, soil type, climate and annual sowing time were created in APSIM. This followed simulation of crop growth, and evapotranspiration across 121 years (1890-2011) of available climate data. The crop was supplied with ample irrigation water to supply any requirements for maximum crop growth. In this respect, the Kc curves produced represent the time averaged maximum possible water demand. The crop Kc factor on each growing day of the year was calculated as per Eq. 1;

$$
K c_{i}=\sum_{j=1}^{n}\left(\frac{E_{i, j}+T_{i, j}}{E T o_{i, j}}\right) \times \frac{1}{n}
$$

where $\mathrm{i}$ refers to the growing day of the year ( $i=1,2,3, \ldots$ harvest day), $j$ is the year of simulation, $n$ is the number of years of simulation (121), E is evaporation from the crop and soil surfaces, $\mathrm{T}$ is the crop transpiration and ETo is potential evapotranspiration.

The constructed Kc curves were loaded into the Source crop model for simulation of crop water supply, given system constraints, and the nature of the simulated irrigation development.

\subsubsection{Evaluating the Response of Crop Yield to Water Stress for a Large Number of Simulations}

To evaluate the sensitivity of crop yield to water stress, rather than inputting to APSIM the time series of water that could be supplied to the sorghum crop, this study used a computationally efficient statistical model that related modelled APSIM crop yield to APSIM crop water use (i.e. the sum of irrigation water and rainfall) and climate parameters. Here a generalised additive model with spline smoothing was implemented (Hastie 1990) to assess the effect of irrigation water supply on crop yield, given climate inputs. Knowledge of the physiology of sorghum were used to ensure appropriate climate parameters were captured in the model. This method enabled crop yields to be calculated quickly for the large number of Source river model simulations (e.g. >100) that were used to explore the parameter space. This process would have taken several orders of magnitude longer had the APSIM model been directly coupled to the Source model. Eq. 2 describes the regression model used to estimate crop yield as a function of crop water use and climate;

$$
Y=\beta_{0}+s_{1}(\text { pre.sow })+s_{2}(\text { early })+s_{3}(\text { late })+s_{4}(\text { irri })+s_{5}(\text { rad })+\varepsilon
$$

Where $\mathrm{Y}$ is crop yield, pre.sow is the precipitation ( $\mathrm{mm}$ ) falling from 1 January until sowing (15 March), early is the precipitation ( $\mathrm{mm}$ ) falling from sowing until 78 days after sowing, late is precipitation falling 79 days after sowing until crop maturity, irri is the irrigation supplied $(\mathrm{mm})$ to the crop by the river system (from Source model), and $\mathrm{rad}$ is the solar radiation $\left(\mathrm{MJ} . \mathrm{m}^{-2}\right.$ ) received at the location from sowing to crop maturity. The terms $s_{1}$ to $s_{5}$ refer to the smoothing applied to the independent data within the model, and $\epsilon$ is error. The data for the regression model was generated by running the APSIM crop model across 121 years of climate data for each of a sequence of irrigation water availabilities ranging from 0 to $700 \mathrm{~mm}$. This produced data that cover all combinations of climate and irrigation water supply.

The main advantage of the regression model approach is its simplicity and simulation speed allowing crop yield to be produced for a large number of irrigation development scenarios. 
Figure $2 \mathrm{a}$ shows the crop yield response to applied irrigation water and Fig. $2 \mathrm{~b}$ shows a comparison of the APSIM yield and the yield predicted (adjusted R-squared is 0.93) using the regression model.

\subsection{Selecting the Appropriate Size of the Irrigation Development and Farmer Risk Profile for a Greenfield Irrigation Site}

Numerous river model simulations were undertaken to explore the profitability of different levels of combined physical and financial risk. To do this the dam - irrigation development was assessed for a large number of different combinations of 'scheme area' and 'crop area decision' (farmer risk). Scheme area refers to the size of the irrigation development and represents the maximum area that can be planted in any 1 year. In greenfield irrigation developments, there is not an existing community of irrigators whose risk behaviour could be replicated in the Source river model. Different levels of farmer risk were instead explored in terms of a 'crop area decision', which was measured by a value in ML/ha. At sowing, the area planted by the Source model was set to equal the water in the storage minus conveyance and application losses, divided by the crop area decision. This means that, for a given volume of water in the storage, the lower the crop area decision, the larger the area that would be planted. It follows that a 2-ML/ha crop area decision will result in a larger area planted than a 4-ML/ha decision, and consequently represent a higher risk. The actual amount of water needed by the crop will be determined by the crop water requirements and climate during that particular growing season. It is independent of the crop area decision. The greater the divergence of the crop area decision below the actual crop water requirement, the higher the risk of water stress induced yield reductions. However, this means maximising gross income in more favourable growing seasons. The greater the divergence of the crop area decision above the actual crop water requirement, the smaller the area of planted crop, although with a reduced risk of water stress induced yield reductions.

The matrix of irrigation development scenarios considered 13 irrigation development areas (from 6000 to 80,000 ha), and 7 crop area decisions (from 2 to 14-ML/ha) to give a total of 91 irrigation development scenarios within the Source river/crop model.

For each river model simulation, annual crop yield was calculated using the statistical relationship based on water that could be supplied to the crop and site-specific climate parameters. The resulting annual crop yields and annual water supply from the Source river

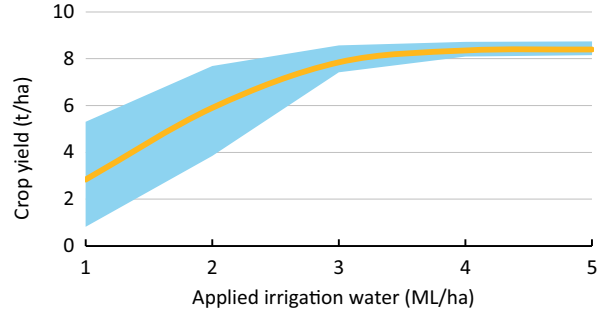

(a)

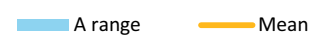

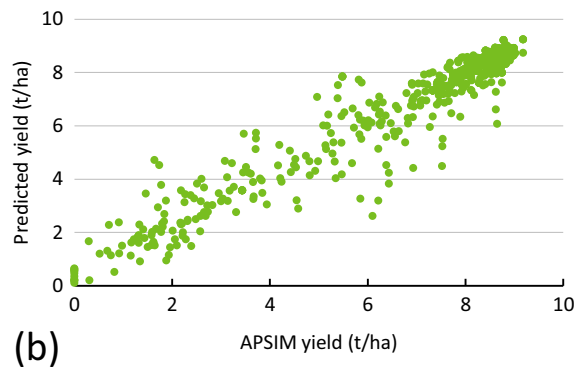

(b)

Fig. 2 Sorghum (grain) yield and applied irrigation water assuming 15 March sowing. (a) Crop yield plotted against applied irrigation water, and (b) crop yield calculated using the Agricultural Production Systems Simulator (APSIM) crop model plotted against that calculated using the statistical model, for sorghum (grain) at Cloncurry under the historic climate (i.e. 1890 to 2011). A range is the range of between the 20th and 80th percentile values 
models were used to calculate annual gross margins and net present value (NPV) at the farm and scheme scale. In this example a constant price for sorghum was assumed based on gross margins calculated by Brennan Mckellar et al. (2013). The purpose was to identify the most profitable irrigation area and crop area decision (i.e. level of farmer risk), which could then be analysed in more detail. The modelling procedure is summarised in Fig. 3.

\subsection{Financial Analysis Framework}

\subsubsection{Overview}

Irrigation development involves a wide range of capital, operation and maintenance costs. These are incurred at both the scheme and farm scale. Scheme-scale costs are those associated with major infrastructure (e.g. dams, channels, roads, earthworks), approvals (e.g. environmental impact statements) and delivery of water to the irrigation development (e.g. pumps). Farm-scale capital, operation and maintenance costs are those associated with irrigation systems and farm equipment.

A financial analysis, also known as an investment analysis, was undertaken at the scheme scale, inclusive of farm-scale costs, with the assumption that costs and benefits are incurred by a single interest. In other words, the analysis treated the whole development as a project conducted by a single developer who incurs all of the costs and receives all of the benefits. The analysis asked 'Are the projected revenues sufficient to cover all expenditures over the life of the development project?' If the net present value (NPV) of the stream of net benefits for the life of the investment is zero or higher, the answer is 'yes'. This approach provides an overall view of the feasibility of the development.

A similar financial analysis could be undertaken at the farm scale where the analysis is framed to assume that irrigators purchase water from scheme water suppliers who bear the scheme capital and operating costs. In these circumstances, investment decisions made by irrigators could be confined to consideration of on-farm costs only. In the interests of brevity, a farm-scale investment analysis is not presented in this paper.

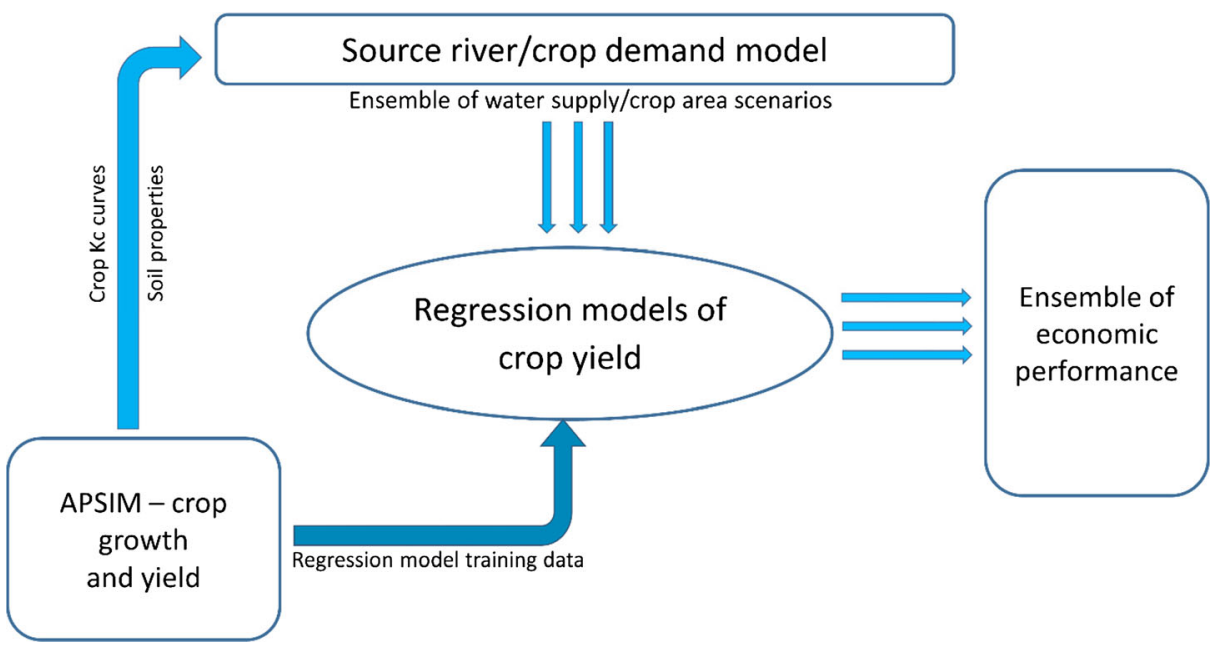

Fig. 3 Schematic representation of the procedure used to assess the profitability of potential irrigation developments 


\subsubsection{Costs of Water Supply and Irrigation Development}

To assess numerous river model simulations for many different irrigation areas, all costs - with the exception of water supply infrastructure and access roads - were reduced to either a per hectare or per megalitre cost (Table 2). The primary assumption is that within the likely range of irrigation areas investigated (e.g. 5000 ha to 40,000 ha), these costs scale linearly. Costs of infrastructure that were independent of the size of the irrigation development (e.g. dam, weirs, main access roads) are listed as a fixed cost. It was assumed that land is not a constraint and that all capital costs were incurred in the first year (i.e. the development was not staged).

\subsubsection{Gross Margin Calculations}

A crop gross margin is the difference between the gross income and variable costs (also known as direct costs) of growing a crop. It does not include overhead or capital costs; these must be met regardless of whether or not a crop is grown. Because variable costs vary directly in proportion to the output of a crop enterprise they were expressed as either a cost per tonne, per hectare, or per ML.

Water charges are also a variable cost when charged on a $\$ / M L$ basis, but are omitted from the gross margin calculations here (pumping costs, however, are included). Instead, as part of this financial analysis, farmers' capacity to pay a water charge can be determined. The crop gross margin is calculated using simulated crop yield and water use. In this example a constant crop gross margin per hectare was assumed. See Brennan McKellar et al. (2013) for inputs to gross margin calculation.

\subsubsection{Financial Analysis}

To assess the profitability of an irrigation development at the scheme and farm scale, the NPV (Eq. 3) was calculated using a discount rate of $7 \%$ over a 30 -year investment period. These assumptions were considered to be consistent with the timeframe and returns expected by private investors for an agricultural investment of this type with risk.

$$
N P V=\sum_{n=0}^{N} \frac{B_{n}-C_{n}}{(1+r)^{n}}
$$

Where:

$B_{n}=$ project benefits in year $n$ expressed in constant dollars.

$\mathrm{C}_{\mathrm{n}}=$ project costs in year $\mathrm{n}$ expressed in constant dollars.

$r=$ real, pre-tax discount rate.

$\mathrm{N}=$ number of years that costs and benefits are produced.

Using the 121 years of historical data (i.e. 1890 to 2011), the total number of 30-year investment windows is 92 . For example, the first 30-year window is 1891 to 1920 , and values are calculated over this window. The second window is 1892 to 1921 , and a second set of values is calculated over this window. This sampling - and subsequent calculating - was repeated 92 times in total, with the final window corresponding to the period from 1982 to 2011. The median value from calculations for each of the 92 windows is presented. The standard deviation of the annual values can be reported to display the variability in 30 year windows. 


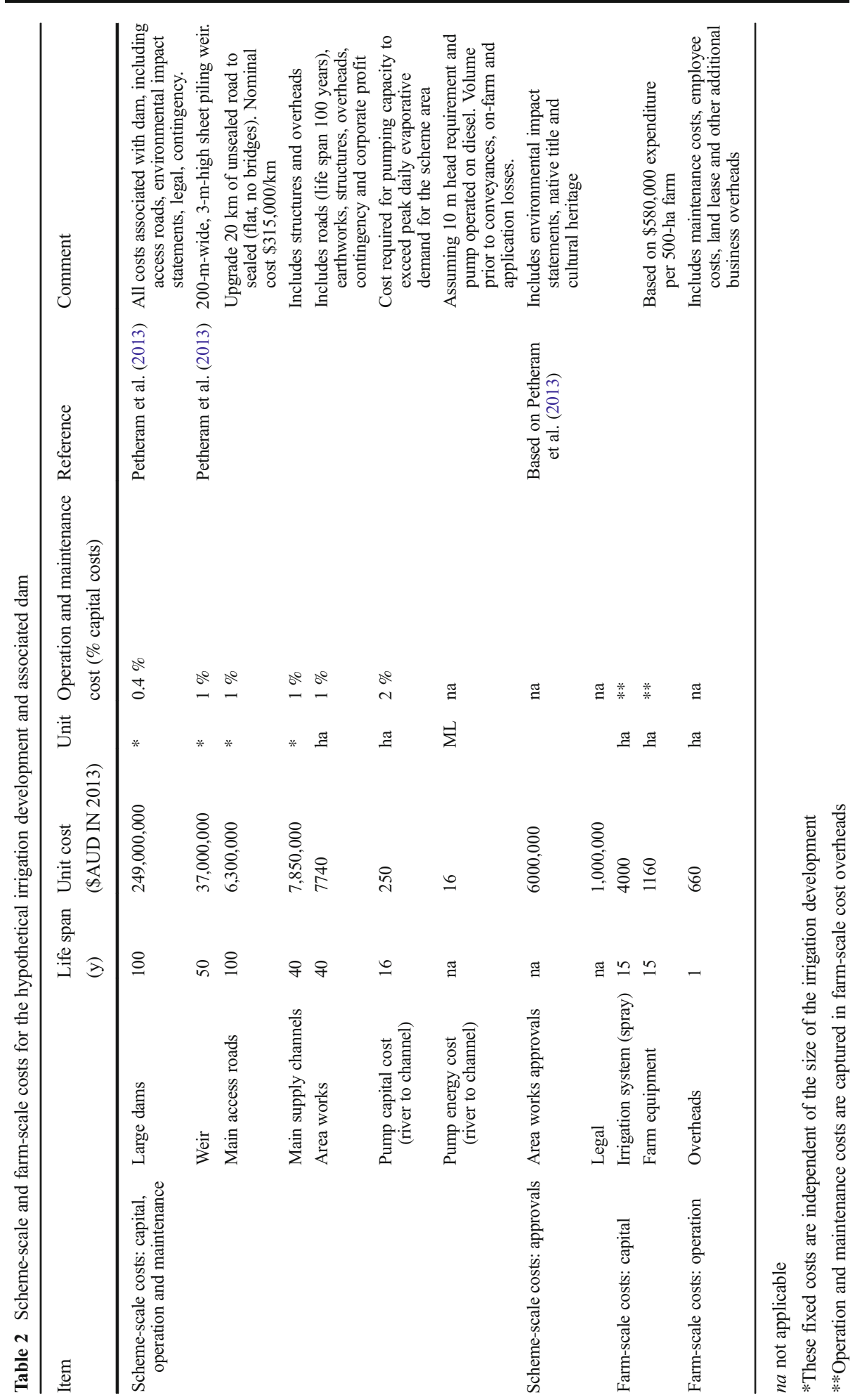


On-farm asset replacement was accounted for at year 16. One of the complications of this type of analysis is that some of the assets have a service life longer than the investment period (e.g. large dams typically have a service life of about 100 years). To calculate the residual value of these assets at the end of the investment period, a straight line depreciation approach was adopted. This approach assumes that the services derived from the asset do not degrade over time, and a maintenance budget is allowed for in the analysis, consistent with the assumption. The assumption may overstate the value, as in reality, dams can experience degradation in the asset value from issues such as silting, leaks and other forms of deterioration. For the farmscale analysis, the average farm size was assumed to be 500 ha, which is close to the average size of a cotton farm in Australia (Cotton Australia 2013).

\section{Results}

\subsection{Crop Yields and Crop Gross Margins}

Figure 4 illustrates the percentage of years that the entire scheme area is planted. Lower crop area decisions result in the entire scheme area being entirely planted a larger proportion of the time. These figures were generated by calculating this value for different combinations of scheme area and crop area decision, and then presenting the information as a contour plot. The different shades of blue and red indicate the proportions of years the maximum area (i.e. scheme area) was planted, as indicated by the legend on the right side of the plot. For example, in Fig. 4 for a scheme area of 20,000 ha and a crop area decision of $3 \mathrm{ML} /$ ha the scheme area is fully planted $50 \%$ of the time. Here plots are provided for crop yields, crop gross margins and net present values but similar plots could also be generated to explore median annual applied irrigation water volume, reservoir evaporation or percentage of time reservoir is less than $20 \%$ of the full supply volume (e.g. could be used to explore recreation amenity of reservoir).

Total crop yields from a scheme area are highest for larger scheme areas and smaller crop area decisions (Fig. 5a). This is because, in the years the reservoir is full or nearly full, the

Fig. 4 Percentage of time scheme area is fully planted

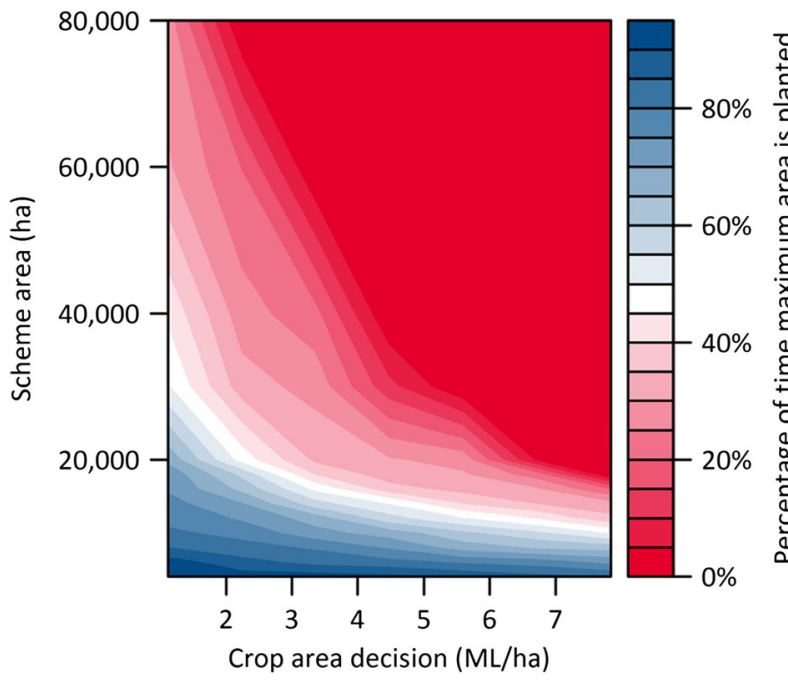



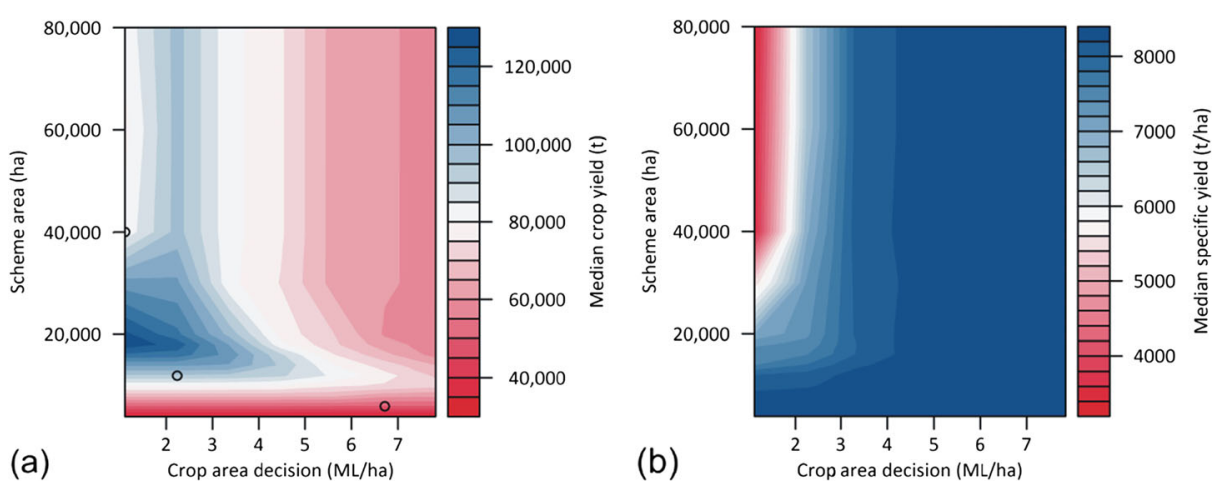

Fig. 5 a Median annual crop yield (t) and b median annual specific crop yield ( $t /$ ha). Circles in (a) indicate the time series selected for demonstrating the variability in annual crop yield presented in Fig. 6

planted area is less constrained by the scheme area. It also occurs because reducing water to the crop by $50 \%$ (from the full median requirement of $4 \mathrm{ML} /$ ha to $2 \mathrm{ML} / \mathrm{ha}$ ) reduces crop yield by only $25 \%$ (Fig. 2). The specific yield (i.e. yield per hectare planted) decreases with lower crop area decision, because at low crop area decisions, sorghum crops are more often under water stress and have lower yields (Fig. 5b).

Although the crop yields are higher for larger scheme areas and smaller crop area decisions, the variability in crop yields is also higher (Fig. 6). The higher crop yields and higher variability for larger scheme areas are illustrated in Fig. 6 with three combinations of scheme area and crop area decision shown by the circles in Fig. 5a. Although the 6000-ha 6.72-ML combination has the lowest total crop yield, in only a few years $(\sim 7 \%)$ is there a complete crop failure. An irrigation development with a 40,000-ha 1.12-ML combination is unlikely to be able to provide drought relief because there will be no water in the storage in the dry years ( $20 \%$ ); it all would have been used in the previous season (Fig. 6).

Low crop yields per hectare result in low gross margins per hectare (Fig. 7a). However, low gross margins per hectare over a large planted area (e.g. scheme area of 40,000 ha and crop area decision of $4 \mathrm{ML} / \mathrm{ha}$ ) can result in higher total gross margins from the scheme area than a high gross margin per hectare occurring over a smaller planted area (e.g. scheme area of 10,000 ha

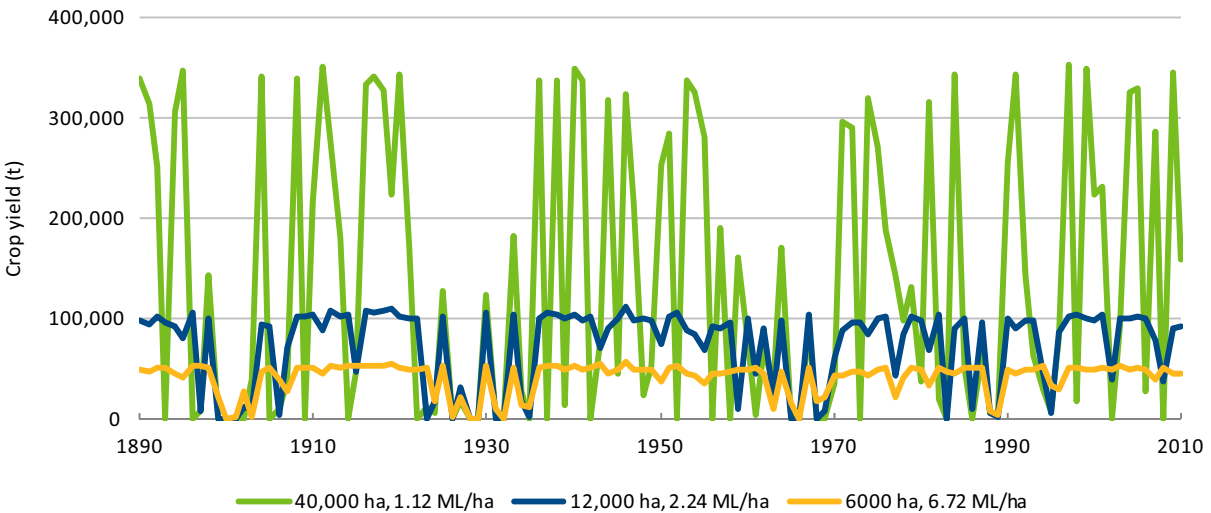

Fig. 6 Annual crop yield for three different scheme area - crop area decision combinations 

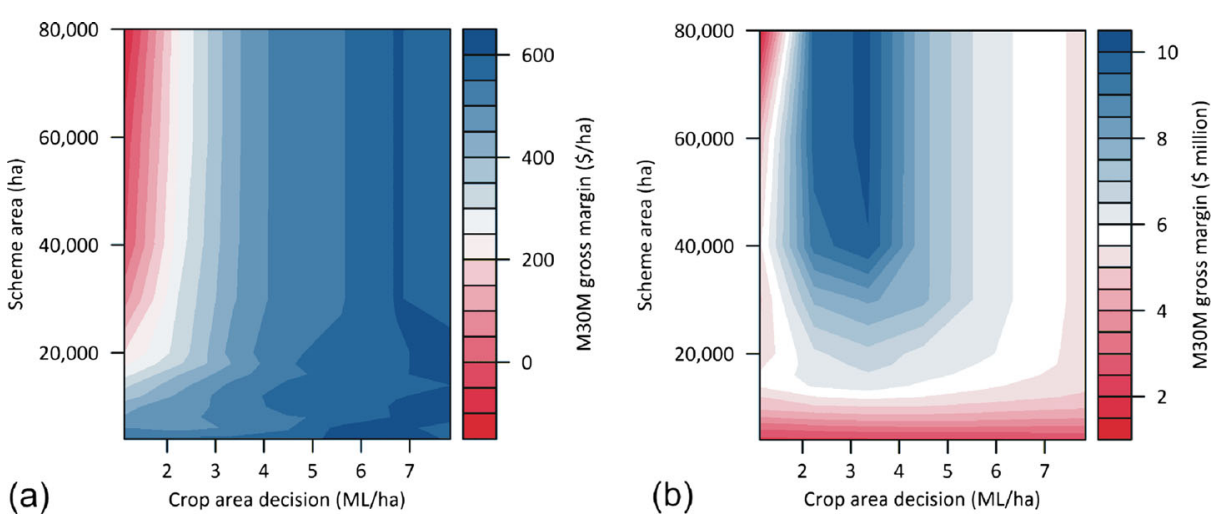

Fig. 7 a Median of the 30-year mean values for gross margin per hectare b median of the 30-year mean values $(\mathrm{M} 30 \mathrm{M})$ for gross margin

and crop area decision of $8 \mathrm{ML} / \mathrm{ha}$ ) (Fig. 7b). Negative gross margins occur under a small set of circumstances, when yields are too low to generate income sufficient to cover the variable costs.

Median 30-year average scheme-scale gross margins increase with scheme area up to the size at which the scheme area no longer constrains the planted area. Gross margins remain the same for larger scheme areas. The largest scheme-scale crop gross margins occur at a crop area decision of between 3 and $4 \mathrm{ML} / \mathrm{ha}$ and at a scheme area of about 45,000 ha (Fig. 7b).

\subsection{Financial Analysis}

The scheme-scale NPV is negative under all combinations of scheme area and crop area decision, because the revenue generated from the scheme (total crop gross margins) does not offset the capital, operation and maintenance costs of the scheme-scale and on-farm infrastructure over the life of the investment (Fig. 8). Losses are minimised by not undertaking an irrigation development. The variation in the 30-year scheme-scale NPV increases for combinations of large scheme area and small crop area decision.

\section{Discussion}

\subsection{Applicability of Method and Sources of Uncertainty}

This paper outlines a robust method that can be used to help evaluate the maximum profit that could be derived from a greenfield irrigation scheme, taking into consideration the economic trade-offs between scheme area, capital and operation costs, physical and farmer risk and crop yield sensitivity to water stress. The method could also be used to explore the impact of different management strategies on the agricultural production and profitability of existing irrigation schemes within a whole of river system context. Results are presented as contour plots illustrating the trade-off between scheme area and level of risk (crop area decision), and this is undertaken for a wide range of variables to help facilitate understanding of the system. These include water applied to the crop, evaporation from the reservoir, crop yield, crop gross margin, and most importantly NPV results presented at the scheme and farm scale. Because the underlying framework uses a whole of catchment Source river model the results could be 

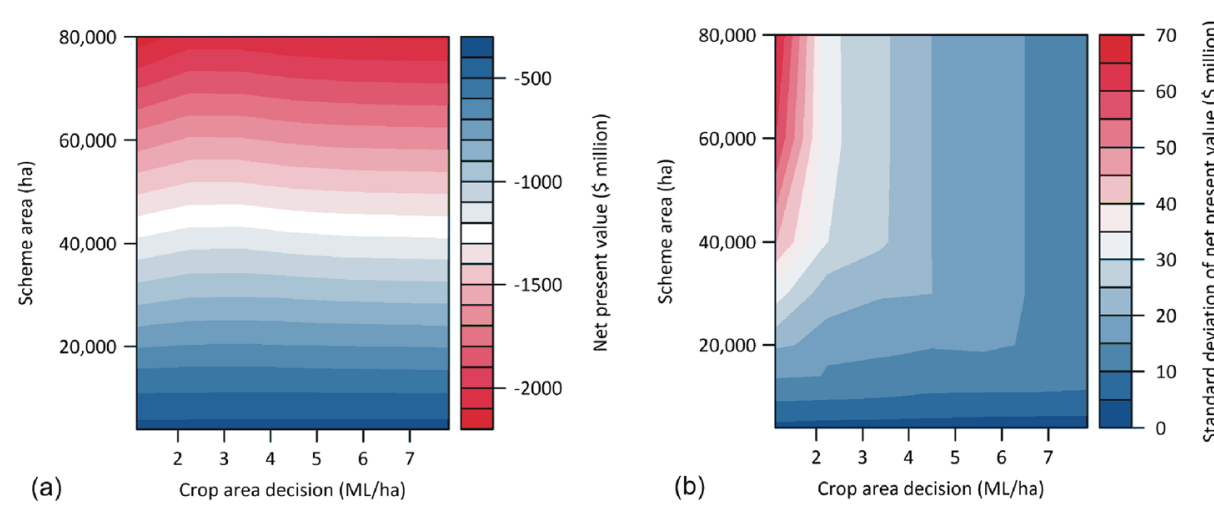

Fig. 8 a Median of the 30-year net present values and $\mathbf{b}$ standard deviation of the 30 -year net present values

extended beyond those presented in this paper to include an assessment of other parameters such as downstream perturbations to flow (e.g. McJannet et al. 2014), inundation of wetlands (Karim et al. 2015) and an assessment of the impacts on downstream users of different scheme area and crop area decision combinations.

The strength of the method is being able to evaluate the sensitivity of the crop yield to the availability of water and in being able to evaluate all decisions in terms of an economic outcome. As with all methods there are a number of sources of uncertainty, primary sources of which are discussed below. Quantification of the uncertainties in the bio-physical modelling and economic modelling will be explored in a future paper.

\subsubsection{Model Uncertainty}

Potential sources of uncertainty may include: input data to the hydrological model (e.g. streamflow data, rainfall data; Shao et al. 2014); model non-uniqueness (Beven and Freer (2001); uncertainty in the crop biophysical modelling (e.g. soil parameters, climate data, APSIM sorghum module parameters); and uncertainty in the scheme and farm scale cost estimates.

Uncertainty could also arise from the novel method of using crop factors and a regression relationship to link the Source crop model to the APSIM biophysical crop model. While this simplifies the relationship between yield and water availability and reduces computational time it could introduce an additional source of uncertainty. However, undertaking the assessment using the regression approach method and then input applied water from Source directly into APSIM, rather than using the regression model, did not result in large changes to the median NPV at the scheme or farm scale (i.e. less than $\pm 10 \%$ ). It is possible that other crops may not be as well characterised by a regression relationship.

\subsubsection{Uncertainty in the Economic Analysis}

Assumptions in financial analysis (e.g., discount rate, length of investment window, prices) are also likely to have a strong bearing on the end result. Price fluctuations were not considered in this analysis but it would be possible to substitute a temporal pattern of price fluctuations for the fixed price value used in this analysis e.g. where the temporal pattern of price fluctuations could be randomly generated or generated by correlating price with regional climate variables. 
This may be particularly important where prices are correlated to regional rainfall. The price for fodder for example increases during dry periods when there is little grazing available.

\subsubsection{Production Risks}

It is very important to recognise that actual on-farm crop yields are highly dependent on the critically important - yet difficult to define - trait of 'management skill', the process by which the best decisions and actions occur at the best times. This grows with experience and, until it reaches a high level, the challenges associated with the relative lack of cropping experience in the regions should not be underestimated. Until a pool of expertise develops and builds over several years, with the growing ability to anticipate challenges that first need to be experienced (such as pest and disease pressures), actual crop yields would be expected to be significantly lower than potential crop yields. The difference between actual and potential crop yields, often referred to as the 'yield gap', usually closes slowly over time, and this needs to be factored into individual enterprise and regional development plans.

Not considered in this analysis were non-climate related production risks, such as pests, weeds and trafficability. The first two are very difficult to incorporate into agricultural production analysis and consequently the yield values reported in this study must be considered potential yield values. Although median rainfall during a March sowing is relatively low $(30 \mathrm{~mm})$, wetter years on these high clay content soils may result in delayed crop establishment because of access problems for cultivation and planting machinery. Although not undertaken in this analysis it would be possible to incorporate sowing rules based on antecedent conditions within the Source modelling framework.

\section{Conclusions}

This paper provides an outline for the efficient linkage of a river system model and an agricultural production model for the purpose of evaluating the most profitable greenfield irrigation scheme area and level of farmer risk. The method could also be used to explore the most profitable strategies for managing existing irrigation schemes. The main inputs to the method are a pre-calibrated river system model and agricultural productivity model, a scheme configuration and associated capital and operational cost information. Regression models were used to provide quick and efficient linkage of the river system model and the agricultural production model. The results of the method can be displayed as a series of multi-dimensional contour plots there by enabling the results of trade-off in scheme area, capital and operating, physical and farmer risk and the sensitivity of crop yield to water stress to be visually evaluated. The method can be easily implemented within existing river system modelling frameworks, which enables other types of analysis (e.g. ecological assessments, impacts of water resource development elsewhere in the catchment) to be performed simultaneously.

Acknowledgments Major funding for the Flinders and Gilbert Agricultural Resource Assessment was provided by the Office of Northern Australia and the Australian Government's Northern Australia Sustainable Futures program. CSIRO co-invested through its Water for a Healthy Country and Sustainable Agricultural flagships. The authors would also like to thank Dr. Mac Kirby (CSIRO) and two anonymous reviewers for comments on drafts of this paper. 
Open Access This article is distributed under the terms of the Creative Commons Attribution 4.0 International License (http://creativecommons.org/licenses/by/4.0/), which permits unrestricted use, distribution, and reproduction in any medium, provided you give appropriate credit to the original author(s) and the source, provide a link to the Creative Commons license, and indicate if changes were made.

\section{References}

ABC Rural (2014). Queensland dams dominate, but irrigators lukewarm on cost of water in agriculture green paper. Retrieved from http:/www.abc.net.au/news/2014-10-21/resurrection-of-queensland-dams-welcomedbut-irrigators-not-sure/5830478 on 3 March 2015

AECOM (2009). Flinders River Off-Stream Storage. Prefeasibility Scheme. Richmond Shire Council. Job No. 60027902. July 2009

Allen RG, Pereira LS, Raes D, Smith M (1998) Crop evapotranspiration - Guidelines for computing crop water requirements-FAO Irrigation and drainage paper 56. FAO_Food and Agriculture Organization of the United Nations, Rome

Ansar A et al. (2014) Should we build more large dams? The actual costs of hydropower megaproject development. Energy Policy. doi:10.1016/j.enpol.2013.10.069i

AQUASTAT (2015) http://www.fao.org/nr/water/aquastat/main/index.stm

Bartley R, Thomas MF, Clifford D, Phillip S, Brough D, Harms D, Willis R, Gregory L, Glover M, Moodie K, Sugars M, Eyre L, Smith DJ, Hicks W, Petheram C (2013) Land suitability: technical methods. A technical report to the Australian Government from the Flinders and Gilbert Agricultural Resource Assessment, part of the North Queensland Irrigated Agriculture Strategy. CSIRO Water for a Healthy Country and Sustainable Agriculture flagships, Australia

Bethune, M and G Podger (2013) 'Irrigator Demand Model', in Kelley, P. \& O'Brien, A. (eds) 2012, Source Scientific Reference Guide, eWater Cooperative Research Centre, Canberra, Australia, https://ewater. atlassian.net/wiki/display/SD35/Irrigator+Demand+Model+-+SRG

Beven K, Freer JE (2001) Equifinality, Data assimilation, and uncertainty estimation in mechanistic modelling of complex environmental systems using the GLUE methodology. J Hydrol 249:11-29

Brennan McKellar L, Monjardino M, Bark R, Wittwer G, Banerjee O, Higgins A, MacLeod N, Crossman N, Prestwidge D and Laredo L (2013) Irrigation costs and benefits. A technical report to the Australian Government from the CSIRO Flinders and Gilbert Agricultural Resource Assessment, Part of the North Queensland irrigated agriculture strategy. CSIRO Water for a Healthy Country and Sustainable Agriculture flagships, Australia

Burnash RJC, Ferral RL, McGuire RA (1973). A generalized streamflow simulation system: Conceptual modelling for digital computers. U.S. Department of Commerce, National Weather Service, and State of California, Department of Water Resources Rep., 204 pp

Cotton Australia (2013). A collection of statistics across 20 key areas of Australian cotton production. Cotton Australia. Retrieved on 1 July 2016 from http://cottonaustralia.com.au/uploads/publications/2013_Cotton_ Annual___Statistics_Booklet.pdf

Davidson B (1972) The northern myth: a study of the physical and economic limits to agricultural and pastoral development in tropical Australia. Melbourne University Press, Melbourne

DEEDI (2011) Cropping and grazing systems for Flinders River Agricultural Precinct Development Project. A case study analysis. Department of Employment Economic Development and Innovation Report, Queensland Government

Fan S, Brzeska J, Shields G (2007) Investment Priorities for Economic Growth and Poverty Reduction, 2020 Focus Brief on the World's Poor and Hungry People IFPRI. Washington, DC

Hastie T (1990) Generalized Additive Models. Chapman and Hall

Hassanzadeh E, Elshorbagy A, Wheater H, Gober P (2014) Managing water in complex systems: An integrated water resources model for Saskatchewan, Canada. Environmental Modelling \& Software 58:12-26

Karim F, Dutta D, Marvanek S, Petheram C, Ticehurst C, Lerat J, Kim S, Yang A (2015) Assessing the impacts of climate change and dams on floodplain inundation and wetland connectivity in the wet-dry tropics of northern Australia. J Hydrol 522, 80-94

Keating BA, Carberry PS, Hammer GL, Probert ME, Robertson MJ, Holzworth D, Huth NI, Hargreaves JNG, Meinke H, Hochman Z, McLean G, Verburg K, Snow V, Dimes JP, Silburn M, Wang E, Brown S, Bristow KL, Asseng S, Chapman S, McCown RL, Freebairn DM, Smith CJ (2003) An overview of APSIM, a model designed for farming systems simulation. Eur J Agron 18:267-288

Kingsford R (2000) Ecological impacts of dams, water diversions and river management on floodplain wetlands in Australia. Austral Ecology 25:109-127

Lange J (2005) Dynamics of transmission losses in a large arid stream channel. J Hydrol 306(1-4):112-126 
Laurenson EM (1959) Storage analysis and flood routing in long river reaches. J Geophys Res 64:2423-2431. doi:10.1029/JZ064i012p02423

Lerat J, Egan C, Kim S, Gooda M, Loy A, Shao Q, Petheram C (2013) Calibration of river models for the Flinders and Gilbert catchments. A technical report to the Australian Government from the CSIRO Flinders and Gilbert Agricultural Resource Assessment, Part of the North Queensland irrigated agriculture strategy. CSIRO Water for a Healthy Country and Sustainable Agriculture flagships, Canberra, Australia

Meateng et al. (2012) Evaluating the commercial viability of a northern outback Queensland meat processing facility. Meateng Pty Ltd, Melbourne

McJannet D, Marvanek S, Kinsey-Henderson A, Petheram C, Wallace J (2014) Persistence of in-stream waterholes in ephemeral rivers of tropical northern Australia and potential impacts of climate change. Mar Freshw Res 65(12):1131-1144. doi:10.1071/MF14035

Molle F (2008) Why Enough Is Never Enough: The Societal Determinants of River Basin Closure. International Journal of Water Resources Development 24:217-226

Morwood (1983) Preliminary Environmental Assessment of the Proposed Glendower Damsite on the Flinders River North Queensland

NQ Register (2014). New dam for Cloncurry. Retrieved from http://www.northqueenslandregister.com.au/news/ agriculture/general/news/new-dam-for-cloncurry/2688115.aspx on 3 March 2015

Petheram C, Rogers L, Eades G, Marvanek S, Gallant J, Read A, Sherman B, Yang A, Waltham N, McIntyreTamwoy S, Burrows D, Kim S, Podger S, Tomkins K, Poulton P, Holz L, Bird M, Atkinson F, Gallant S and Kehoe M (2013) Assessment of surface water storage options in the Flinders and Gilbert catchments. A technical report to the Australian Government from the CSIRO Flinders and Gilbert Agricultural Resource Assessment, Part of the North Queensland irrigated agriculture strategy. CSIRO Water for a Healthy Country and Sustainable Agriculture flagships, Australia

PMC (2014) Green paper on developing northern Australia. Australian Government Department of Prime Minister and Cabinet

Shao Q, Lerat J, Podger G, Dutta D (2014). Uncertainty estimation with bias-correction for flow series based on rating curve. J Hydrol, 2014, 137-152

Stirzaker RJ (1999) The problem of irrigated horticulture: matching the biophysical efficiency with the economic efficiency. Agrofor Syst 45:187-202

UNESCO (2009): Water in a changing world. United Nations World Water Development Rep. 3, 349 pp. [Available online at http://www.unesco.org/water/wwap/wwdr/wwdr3/pdf/WWDR3_Water_in_a_ Changing_World.pdf.]

Vaze J, Viney N, Stenson M, Dijk AV, Dutta D, Crosbie R, Lerat J, Penton D, Vleeshouwer J, Teng J, Kim S, Hughes J, Dawes W, Zhang Y, Leighton B, Perraud J-M, Yang A, Wang B, Frost A, Elmahdi A, Smith A, Daamen C (2013). The Australian Water Resource Assessment Modelling System (AWRA) 20th International Congress on Modelling and Simulation

Vorosmarty CJ, Meybeck M, Fekete B, Sharma K, Green P, Syvitski PM (2003) Anthropogenic sediment retention: major global impact from registered river impoundments. Glob Planet Chang 39:169-190

WCD (2000) Dams and Development. A new framework for decision-making. World Commission on Dams Earthscan Publications Ltd, London and Sterling, VA

Welsh WD, Vaze J, Dutta D, Rassam D, Rahman JM, Jolly ID, Walbrink P. Podger G, Bethune M, Hardy JM, Teng J, Lerat J (2012). An integrated modelling framework for regulated river systems Environmental Modelling and Software 